\title{
EKSPERIMENTASI MODEL PEMBELAJARAN COOPERATIVE SCRIPT PADA PEMBELAJARAN MATEMATIKA
}

\author{
Robia Astuti ${ }^{1}$, Nurmitasari ${ }^{2}$, Sutanti Diah Lestari ${ }^{3}$ \\ 1,2,3 Program Studi Pendidikan Matematika, STKIP Muhammadiyah Pringsewu Lampung \\ email: ${ }^{1}$ robia.astuti@ stkipmpringsewu-lpg.ac.id, \\ ${ }^{2}$ nurmitasari@stkipmpringsewu-lpg.ac.id
}

\begin{abstract}
The aimed of this research was: 1) to know the difference of the average of mathematics learning result of students obtained through Cooperative Script model with the average of student learning result obtained through STAD type cooperative learning model in class VII class material in SMP Negeri 1 Banyumas, and 2) to know the average of mathematics learning outcomes which is better between students whose learning is obtained through Cooperative Script model with students whose learning is obtained through STAD type cooperative learning model in class VII class material in SMP Negeri 1 Banyumas. The population in this study is all students of class VII even semester SMP Negeri 1 Banyumas academic year 2016-2017 with the number of 162 students divided into 5 (five) class. The sampling technique uses cluster random sampling. Obtained Class VII A amounted to 33 students as experimental class and class VII B which amounted to 33 students as a control class. Learning outcomes obtained through the test in the form of a description consists of 4 items. Data were analyzed using two-t test and one-party test. Data analysis using two-party $t$ test with $5 \%$ real level obtained by result of $t_{\text {table }}=1,999$ and $t_{\text {count }}=2,602, t_{\text {table }}<t_{\text {count }}$, so reject $H_{0}$ and accept $H_{1}$ which indicate that there is difference of mean result of learning of mathematics between them. Analysis of data using t-test one party with $5 \%$ real level obtained $t_{\text {table }}=1.670$ and $t_{\text {count }}=2.602$ turns $t_{\text {table }}<t_{\text {count }}$, so $H_{0}$ rejected and accepted $H_{1}$ which indicates that the average mathematics learning outcomes of students applied Cooperative Script learning model more both from the STAD type cooperative learning model. The result of t test analysis concluded that there is influence of Cooperative Script model to the result of learning of class VII in SMP Negeri 1 Banyumas.
\end{abstract}

Keywords: Cooperative Script model, STAD type cooperative learning model, Segiempat

\section{A. PENDAhULUAN}

Matematika merupakan salah satu ilmu pengetahuan dasar untuk melatih berfikir kritis, kreatif, sistematis, logis dan mempunyai kemampuan kerja sama yang efektif. Cara berpikir seperti ini dapat dikembangkan melalui belajar matematika yang memiliki struktur sistematis serta proses yang jelas dengan keterkaitan konsep yang dipelajari. Upaya yang dilakukan oleh pemerintah untuk meningkatkan mutu pendidikan di Indonesia, diantaranya dengan diberlakukannya Kurikulum 2013. Kurikulum 2013 yaitu kurikulum operasi- 
onal yang disusun sebagai pedoman penyelenggaraan kegiatan pembelajaran untuk mencapai tujuan pendidikan tertentu. Tujuan tersebut meliputi tujuan pendidikan nasional serta kesesuaian dengan kekhasan, kondisi, potensi daerah, satuan pendidikan dan siswa. Oleh sebab itu setiap satuan pendidikan diberikan keleluasaan untuk mengembangkan kurikulum sekolah sendiri agar sesuai dengan kebutuhan dan potensi daerahnya. Upaya untuk mencapai tujuan tersebut, maka setidaknya pembelajaran yang dilakukan antara guru dan siswa hendaknya mengacu pada peningkatan proses berpikir dalam menemukan konsep agar siswa mudah dalam menyelesaikan soal. Guru tidak hanya melakukan kegiatan penyampaian pengetahuan saja, tetapi guru mengarahkan keterampilan siswa untuk mengembangkan konsep berupa belajar penemuan, belajar mandiri, belajar kelompok, dan belajar memecahkan masalah.

Hasil pra pengamatan peneliti di SMP Negeri 1 Banyumas kegiatan pembelajaran yang dilakukan guru sudah menggunakan pembelajaran kelompok untuk memecahkan masalah yang diberikan. Proses pembelajaran kelompok yang dilakukan guru, guru sudah mencoba memberikan kesempatan kepada siswa untuk diskusi dengan teman dalam kelompoknya dalam menyelesaikan masalah yang diberikan, guru membimbing siswa untuk memahami masalah dalam menyelesaikan permasalah- an dengan menggunakan konsep yang tepat, berdasarkan keterangan tersebut, guru sudah melaksanakan pembelajaran sesuai dengan pembelajaran kooperatif tipe STAD.

Pembelajaran kooperatif tipe Student Team Achievement Division (STAD) ini merupakan merupakan pendekatan pembelajaran kooperatif yang paling sederhana. Model pembelajaran kooperatif tipe STAD menggunakan kelompok-kelompok kecil dengan jumlah anggota tiap kelompok 4-5 orang secara heterogen. Diawali dengan penyampaian tujuan pembelajaran, penyampaian materi, kegiatan kelompok, kuis dan penghargaan kelompok. Slavin (dalam Trianto, 2010:69) menyatakan seperti halnya pembelajaran lainnya, pembelajaran kooperatif tipe STAD ini juga membutuhkan persiapan yang matang sebelum kegiatan pembelajaran dilaksanakan.

Namun, diskusi kelompok yang dilakukan masih kurang kondusif, terlihat beberapa siswa yang mempunyai kemampuan rendah hanya mengandalkan rekannya dalam kelompok belajarnya, sedangkan siswa yang mempunyai kemampuan tinggi mendominasi proses diskusi tersebut, sehingga saat diberikan soal untuk diselesaikan secara individu masih banyak siswa bingung dan bahkan banyak siswa yang tidak bisa menyelesaikan soal tersebut terkhusus pada materi segiempat sehingga hasil belajar 
siswa rendah. Hasil belajar siswa yang rendah terlihat dari pencapaian hasil belajar pada materi segiempat yang masih dibawah KKM (Kriteria Ketuntasan Minimum) yang ditetapkan sekolah yaitu 70 yang terlihat pada Tabel 1 sebagai berikut.

Tabel 1

Hasil Ulangan Harian

\begin{tabular}{|c|c|c|c|c|}
\hline \multirow[b]{2}{*}{ No } & \multirow{2}{*}{ TA } & \multirow{2}{*}{$\begin{array}{c}\text { Jumlah } \\
\text { siswa }\end{array}$} & \multicolumn{2}{|c|}{ Nilai KKM } \\
\hline & & & $0 \leq x<70$ & $70 \leq x \leq 100$ \\
\hline 1 & $2015-2016$ & 132 & 75 & 57 \\
\hline & Presentasi & $100 \%$ & $56,81 \%$ & $43,19 \%$ \\
\hline
\end{tabular}

Data pada tabel 1 adalah data ulangan harian kelas VII SMP N 1 Banyumas memperlihatkan bahwa hasil belajar siswa pada materi Segi empat tahun pelajaran 2015-2016 dari 4 kelas diperoleh persentase nilai yang mencapai KKM sebesar $43,19 \%$.

Hasil belajar matematika siswa yang optimal tidak terlepas dari peran guru. Kegiatan pembelajaran setidaknya lebih membuat siswa kreatif dalam pembelajaran. Oleh karena itu, dalam pembelajaran guru harus benar-benar memilih model pembelajaran yang sesuai dengan materi yang akan disampaikan dalam belajar agar tercipta proses pembelajaran yang diinginkan. Hal ini dapat dilakukan dengan cara menerapkan model pembelajaran yang melibatkan siswa dalam bekerja dan saling membantu antar siswa dalam memecahkan masalah yang dibantu dengan sebuah wacana agar siswa memahami tujuan atau permasalahan yang diberikan. Model pembelajaran kooperatif merupakan salah satu alternatif untuk membantu siswa mengacu pada cara pembelajaran yang mana siswa bekerja bersama dalam kelompok kecil saling membantu dalam belajar, anggota kelompok bertanggungjawab atas ketuntasan tugas-tugas kelompok dan untuk mempelajari materi itu sendiri. Model pembelajaran kooperatif memiliki banyak jenis antara lain: Student Teams Achievement (STAD), Teams Games Tornament (TGT), Teams Assisted Instruction (TAI), Group Investigation (GI) Jigsaw, Cooperative Script, Number Heads Together (NHT) dan lain-lain. Masingmasing tipe model pembelajaran kooperatif tersebut memiliki karakteristik yang berbeda, sehingga dalam penelitian ini peneliti memfokuskan pada model Cooperative Script untuk mengubah pola pembelajaran pendidik yang biasa diterapkan di SMP Negeri 1 Banyumas dalam mengajar di kelas.

Menurut Lambiotte (dalam Huda, 2013:213) "pembelajaran cooperative script adalah salah satu pembelajaran dimana siswa bekerja secara berpasangan dan bergantian secara lisan dalam mengikhtisarkan bagian-bagian materi yang dipelajari". Jadi, model pembelajaran Cooperative Script merupakan penyampaian materi ajar yang diawali dengan pemberian wacana atau ringkasan materi 
ajar kepada siswa yang kemudian diberikan kesempatan kepada siswa untuk membacanya sejenak dan memberikan atau memasukkan ide-ide atau gagasan-gagasan baru kedalam materi ajar yang diberikan guru, lalu siswa diarahkan untuk menunjukkan ide-ide pokok yang kurang lengkap dalam materi yang ada secara bergantian sesama pasangan masingmasing sehingga siswa yang berkemampuan rendah tidak hanya mengandalkan rekannya yang berkemampuan tinggi. Siswa juga dilatih untuk saling bekerja sama satu sama lain dalam suasana yang menyenangkan serta menemukan ide-ide pokok dari gagasan besar yang disampaikan oleh guru. Melalui model pembelajaran Cooperative Script siswa dibimbing untuk terus meningkatkan kemampuan pada aspek kognitif yang diarahkan pada pemahaman konsep secara sistematis dalam membuktikan atau mengimplementasikan konsep yang akan diterapkan dalam menyelesaikan sebuah masalah.

Adapun langkah-langkah pembelajaran cooperative script menurut (Suprijono, 2009:126) yaitu: i) Guru membagi siswa untuk berpasangan, ii) Guru membagikan wacana/materi tiap siswa untuk dibaca dan membuat ringkasan, iii) Guru dan siswa menetapkan siapa yang pertama berperan sebagai pembicara dan siapa yang berperan sebagai pendengar. Sementara pembicara membacakan script, pendengar menyimak/ mengoreksi/menunjukkan ide-ide pokok yang kurang lengkap, iv) Bertukar peran, semula sebagai pembicara ditukar menjadi pendengar dan sebaliknya, v) Setelah pembacaan script selesai, guru dan siswa melakukan diskusi kelas untuk membahas materi yang telah mereka pelajari, vi) Siswa saling berinteraksi bertanya, menjawab, mengemukakan pendapat, menyanggah, dan sebagainya sementara guru memimpin diskusi kelas, diakhir pembelajaran guru memberikan soal latihan dan latihan sebagai pemahaman konsep.

Penerapan model Cooperative Script, diharapkan siswa mengalami kemudahan dalam memahami konsep matematika, sehingga tujuan dari suatu proses pembelajaran dapat dicapai. Tugas guru dalam mencapai tujuan tersebut yaitu membimbing siswa untuk dapat memaksimalkan kompetensi yang dimiliki siswa.

Oleh sebab itu penting untuk dilakukan penelitian dalam model pembelajaran Cooperative Script pada pembelajaran matematika, melalui penerapan model pembelajaran Cooperative Script pada materi segiempat diharapkan dapat meningkatkan hasil belajar matematika siswa. Berdasarkan masalah di atas, peneliti tertarik untuk menerapkan pembelajaran menggunakan model Cooperative Script sehingga diharapkan dapat mendukung proses pembelajaran dan hasil belajar menjadi lebih baik. 


\section{B. METODOLOGI PENELITIAN}

\section{a. Instrumen Penelitian}

Instrumen dalam penelitian adalah soal tes yang bertujuan untuk memperoleh hasil belajar siswa. Tes akan dilakukan setelah siswa yang dijadikan sebagai sampel mendapatkan perlakuan dengan model pembelajaran $\mathrm{Co}$ operative Script (pada kelas eksperimen) dan yang mendapatkan model pembelajaran kooperatif tipe STAD (pada kelas kontrol). Instrument tes yang diberikan dalam bentuk uraian berjumlah 4 soal berdasarkan indikator kompetensi yang akan dicapai. Namun, peneliti membuat 8 soal yang diujicobakan untuk mengantisipasi adanya butir soal yang tidak layak atau tidak terpakai.

Sebelum instrumen digunakan, terlebih dahulu dilakukan pengembangan instrumen untuk mengetahui instrument tersebut layak digunakan atau tidak. Syarat instrument yang layak adalah instrument harus valid dan reliabel. Pengembangan instrument tersebut meliputi validitas, reliabilitas, tingkat kesukaran dan daya pembeda alat tes tersebut.

1) Validitas

Untuk mengetahui validitas suatu instrumen dilakukan dengan validitas isi dan validitas item. Menurut Sugiyono (2010:353) Untuk instrument yang berbentuk tes, maka pengujian validitas isi dapat dilakukan dengan membandingkan antara isi instrument dengan materi pelajaran yang telah diajarkan. Selain validitas isi akan dilihat pula validitas tes tiap item instrument. Hal ini sesuai dengan yang dikemukakan oleh Sugiyono (2010:353) bahwa: "Untuk menguji validitas butir-butir (item) instrumen lebih lanjut, maka setelah dikonsultasikan dengan ahli, maka selanjutnya diujicobakan, dan dianalisis dengan analisis item". Validitas tiap item dilakukan dengan mengkorelasi skor butir soal tersebut dengan skor total yang diperoleh. Koefisien korelasi dihitung dengan rumus korelasi pearson product moment. (Siregar, 2014:237) yaitu:

$$
r_{\text {hitung }}=\frac{n \sum X i Y i-\left(\sum X i\right)\left(\sum Y i\right)}{\left.\sqrt{\left\{n \sum X i^{2}-\left(\sum X i\right)^{2}\right.}\right\}\left\{n \sum Y i^{2}-\left(\sum Y i\right)^{2}\right\}}
$$

2) Tingkat kesukaran

Menurut Surapranata (2009:12) rumus yang digunakan untuk menentukan tingkat kesukaran adalah:

$$
p_{i}=\frac{\sum x_{i}}{S_{m} N}
$$

Keterangan : $p_{i}:$ proporsi peserta tes yang menjawab benar atau tingkat kesukaran, $\sum x_{i}$ : jumlah skor peserta tes, $S_{m}$ : Skor maksimum, $N$ : jumlah peserta tes. 
3) Daya Pembeda Tes

Rumus untuk menghitung daya pembeda dapat digunakan formula sebagai berikut :

$$
D=\frac{\sum A}{n_{1}}-\frac{\sum B}{n_{2}}
$$

Keterangan: $\quad D$ : indeks daya pembeda, $\sum A$ : jumlah skor peserta tes pada kelompok atas dibagi dengan skor maksimum tiap item, $\sum B$ : jumlah skor peserta tes pada kelompok bawah dibagi dengan skor maksimum tiap item, $n_{1}$ : Jumlah peserta tes pada kelompok atas, $n_{2}$ : Jumlah peserta tes pada kelompok bawah.

4) Reliabilitas

Sebagaimana diungkapkan Riduwan (2010 :115), bahwa untuk mengetahui reliabilitas tes pada soal uraian menggunakan rumus Alpha Cronbach, sebagai berikut:

$$
\mathrm{r}_{11}=\left(\frac{\mathrm{k}}{\mathrm{k}-1}\right)\left(1-\frac{\sum \mathrm{s}_{\mathrm{i}}^{2}}{\mathrm{~S}_{\mathrm{t}}^{2}}\right)
$$

\section{b. Populasi, Sampel, dan Teknik Sampling}

Populasi dalam penelitian ini adalah seluruh siswa kelas VII semester genap SMP Negeri 1 Banyumas tahun ajaran 2016/2017 dengan jumlah 162, sampel sebanyak 2 kelas dengan jumlah 66 siswa, dan teknik sampling menggunakan sampel acak klaster (cluster random sampling) yaitu penarikan sampel dari populasi yang telah dikelompokkan.

\section{c. Teknik Analisis Data}

Teknik analisis data yang digunakan dalam penelitian ini adalah uji-t yaitu uji-t satu pihak dan uji-t dua pihak. Namun sebelum menggunakan uji tersebut terlebih dahulu data yang diperoleh harus memenuhi uji normalitas dan uji homogenitas.

Uji normalitas data menggunakan rumus Chi Kuadarat $\left(\chi^{2}\right)$ dengan rumus :

$$
\chi^{2}=\sum_{i=1}^{k} \frac{(f o-f e)^{2}}{f e}
$$

Uji homogenitas menggunakan rumus:

$$
F_{\text {hitung }}=\frac{S_{B}^{2}}{S_{K}^{2}}
$$

Uji hipotesis dilakukan dengan uji t satu pihak dan uji $\mathrm{t}$ dua pihak. Rumus statistik yang digunakan:

$$
t_{\text {hitung }}=\frac{\overline{\mathrm{x}}_{1}-\overline{\mathrm{x}}_{2}}{\sqrt{\frac{\left(\mathrm{n}_{1}-1\right) \mathrm{S}_{1}^{2}+\left(\mathrm{n}_{2}-1\right) \mathrm{S}_{2}^{2}}{\left(\mathrm{n}_{1}+\mathrm{n}_{2}-2\right)}\left(\frac{1}{\mathrm{n}_{1}}+\frac{1}{\mathrm{n}_{2}}\right)}}
$$

\section{HASIL DAN PEMBAHASAN}

\section{a. Hasil Validitas, Tingkat Kesukaran, Daya Pembeda, dan Reliabilitas}

Hasil validasi berdasarkan isi yang dilakukan oleh tiga validator menyatakan bahwa instrumen valid. Analisis data uji coba instrumen, hasil validitas tiap item disajikan pada Tabel 2 berikut. 
Tabel 2

Data Validitas Instrumen

\begin{tabular}{|c|c|c|c|c|}
\hline $\begin{array}{c}\text { Nomor } \\
\text { Item }\end{array}$ & $\begin{array}{c}\mathbf{r} \\
\text { hitung }\end{array}$ & $\mathbf{t}_{\text {hitung }}$ & $\mathbf{t}_{\text {table }}$ & Keputusan \\
\hline 1 & 0,718 & 5,462 & 1,701 & Valid \\
\hline 2 & 0,740 & 5,826 & 1,701 & Valid \\
\hline 3 & 0,672 & 4,802 & 1,701 & Valid \\
\hline 4 & 0,285 & 1,572 & 1,701 & Tdk Valid \\
\hline 5 & 0,921 & 12,481 & 1,701 & Valid \\
\hline 6 & 0,672 & 4,802 & 1,701 & Valid \\
\hline 7 & 0,285 & 1,572 & 1,701 & Tdk Valid \\
\hline 8 & 0,820 & 7,588 & 1,701 & Valid \\
\hline
\end{tabular}

Tabel 3

Hasil Analisis Tingkat Kesukaran

\begin{tabular}{|c|c|c|}
\hline $\begin{array}{c}\text { Nomor } \\
\text { Item }\end{array}$ & $\begin{array}{c}\text { phitung (Tingkat } \\
\text { Kesukaran) }\end{array}$ & Keputusan \\
\hline 1 & 0,627 & Soal Sedang \\
\hline 2 & 0,593 & Soal Sedang \\
\hline 3 & 0,827 & Soal Mudah \\
\hline 4 & 0,087 & Soal Sulit \\
\hline 5 & 0,733 & Soal Sedang \\
\hline 6 & 0,827 & Soal Mudah \\
\hline 7 & 0,087 & Soal Sulit \\
\hline 8 & 0,593 & Soal Sedang \\
\hline
\end{tabular}

Tabel 4

Hasil Analisis Daya Pembeda Tes

\begin{tabular}{|c|c|c|}
\hline $\begin{array}{c}\text { Nomor } \\
\text { Item }\end{array}$ & Daya Pembeda & Keputusan \\
\hline 1 & 0.32 & Baik \\
\hline 2 & 0.31 & Baik \\
\hline 3 & 0.21 & Tidak Baik \\
\hline 4 & 0.07 & Tidak Baik \\
\hline 5 & 0,40 & Baik \\
\hline 6 & 0,21 & Tidak Baik \\
\hline 7 & 0,07 & Tidak Baik \\
\hline 8 & 0,33 & Baik \\
\hline
\end{tabular}

Dari 8 soal yang diuji validitas, tingkat kesukaran, daya pembeda diperoleh 4 soal yang diterima, selanjutnya dari 4 soal tes yang diterima diuji reliabilitas dengan perolehan sebesar 0,821 yang artinya instrumen reliabel. Berdasarkan analisis uji coba instrumen diperoleh kesimpulan bahwa soal yang layak digunakan adalah soal nomor 1, 2, 5 dan 8 dengan status soal diterima baik sedangkan soal nomor 3, 4, 6 dan 7 status soal dibuang.

\section{b. Hasil Normalitas, Homogenitas, dan Analisis Data}

1.) Hasil analisis normalitas data pada kelas eksperimen diperoleh $\quad \chi^{2}{ }_{\text {hitung }}=5,38$ dan diperoleh $\chi_{\text {tabel }}^{2}=11,070$ karena $\chi_{\text {hitung }}^{2}<\chi_{\text {tabel }}^{2}$ maka $\mathrm{H}_{0}$ diterima dan $\mathrm{H}_{1}$ ditolak, maka diambil suatu kesimpulan bahwa sampel pada kelas tersebut berasal dari populasi yang berdistribusi normal.

2.) Hasil analisis normalitas data pada kelas kontrol diperoleh $\chi^{2}{ }_{\text {hitung }}=9,67$ dan diperoleh $\quad \chi_{\text {tabel }}^{2}=11,070 \quad$ karena $\chi_{\text {hitung }}^{2}<\chi_{\text {tabel }}^{2}$ maka $\mathrm{H}_{0}$ diterima dan $\mathrm{H}_{1}$ ditolak, maka diambil suatu kesimpulan bahwa sampel pada kelas tersebut berasal dari populasi yang berdistribusi normal.

3.) Hasil pengujian homogenitas diperoleh $\mathrm{F}_{\text {hitung }}=1,071, \quad$ Selanjutnya membandingkan nilai $F_{\text {hitung }}$ dengan $F_{\text {tabel }}$ dengan dk pembilang $=n-1$ (untuk varians terbesar) dan derajat kebebasan $\mathrm{dk}$ penyebut $=n-1$ (untuk varians terkecil) dengan taraf signifikan $\alpha=5 \%$ harga $\quad F_{\text {tabel }}=1,808$ (interpolasi). Karena $F_{\text {hitung }}<\mathrm{F}_{\text {tabel }}(1,071<1,808)$ maka $\mathrm{H}_{0}$ ditolak dan $\mathrm{H}_{1}$ diterima jadi kedua sampel memiliki varians yang berbeda.

4.)Hasil uji t dua pihak. Hasil perhitungan diperoleh $t_{\text {hitung }}=2,602$ dan diperoleh 
$t_{\text {tabel }}=1,999, \quad$ karena diperoleh $t_{\text {hitung }}=2,602$ lebih dari $t_{\text {tabel }}=$ 1,999 maka tolak $\mathrm{H}_{0}$ dan terima $\mathrm{H}_{1}$. Hal ini menunjukkan bahwa terdapat perbedaan rata-rata hasil belajar matematika siswa yang diperoleh melalui penerapan model pembelajaran Cooperative Script dengan rata-rata hasil belajar matematika siswa yang diperoleh melalui penerapan model pembelajaran Cooperative STAD.

5.)Hasil uji t satu pihak. Hasil perhitungan diperoleh $t_{\text {hitung }}=2,602$ dan diperoleh $t_{\text {tabel }}=1,670, \quad$ karena diperoleh $t_{\text {hitung }}=2,602$ lebih dari $t_{\text {tabel }}=$ 1,670, maka tolak $\mathrm{H}_{\mathrm{o}}$ dan terima $\mathrm{H}_{1}$. Hal ini menunjukkan bahwa rata-rata hasil belajar matematika siswa yang diperoleh melalui penerapan model pembelajaran Cooperative Script lebih baik dari pada rata-rata hasil belajar matematika siswa yang diperoleh melalui penerapan model pembelajaran Cooperative STAD.

\section{c. Pembahasan}

Berdasarkan hasil analisis data terkait uji $\mathrm{t}$ dua pihak diperoleh hasil yaitu $t_{\text {hitung }}=2,602$ dan diperoleh $t_{\text {tabel }}=$ 1,999, karena diperoleh $t_{\text {hitung }}=2,602$ lebih dari $\mathrm{t}_{\text {tabel }}=1,999$ maka tolak $\mathrm{H}_{0}$ dan terima $\mathrm{H}_{1}$. Hal ini menunjukkan bahwa terdapat perbedaan rata-rata hasil belajar matematika siswa yang diperoleh melalui penerapan model pembelajaran Cooperative Script dengan rata-rata hasil belajar matematika siswa yang diperoleh melalui penerapan model pembelajaran Cooperative STAD. Per-bedaan tersebut dikarenakan dalam proses belajar menggunakan model pembelajaran Cooperative Script ber-tujuan untuk mengembangkan aktivitas belajar yang dilakukan guru dan siswa, siswa bertanggungjawab atas belajar mereka sendiri dan berusaha menemukan informasi untuk memecah-kan masalah secara berkelompok. Selain itu, siswa dapat berpartisipasi aktif dengan menjawab pertanyaan, ber-diskusi dan memberikan tanggapan terhadap jawaban dari siswa lain sehingga lebih mudah dalam memahami isi materi pelajaran.

Kelebihan model pembelajaran Cooperative Script yaitu dapat membuat siswa mengatasi kesulitan matematika, karena dengan menggunakan model pembelajaran ini dapat menciptakan lingkungan belajar yang efektif, menyenangkan dan membantu mempercepat dalam proses pembelajaran. Hal ini dapat ditunjukan saat siswa bekerjasama mengerjakan soal-soal yang diberikan. Siswa dilatih untuk berfikir lebih kreatif dalam upaya untuk menyusun soal atau pertanyaan, kemudi-an siswa juga mampu untuk menyelesai-kan soal tersebut secara berkelompok. Hal tersebut sesuai dengan 
penelitian Nura'ini dan Subanji (2012) dengan judul Proses Interaksi Berpikir Siswa pada Pembelajaran Cooperative Script siswa kelas XI MAN Malang II Batu Pokok Bahasan Komposisi Fungsi yang memberikan hasil terjadi proses interaksi berpikir siswa dalam pembelajaran kooperatif model Cooperative Script, dimana keempat subjek penelitian berinteraksi untuk mengonstruksi atau menemukan konsep fungsi komposisi dan menyelesaikan masalah yang berkaitan dengan materi tersebut. Proses interaksi berpikir tersebut terjadi secara multiarah pada saat belajar kelompok, yaitu antara siswa berkemampuan tinggi, siswa berkemampuan sedang dan siswa berkemampuan rendah dengan Lembar Kegiatan Siswa (LKS). Interaksi yang terjadi dalam proses pembelajaran memberikan dam-pak yang positif bagi siswa, hal tersebut sesuai dengan penelitian yang dilakukan bahwa penerapan model pembelajaran $\mathrm{Co}$ operative Script memberikan perbedaan rata-rata hasil belajar siswa dibandingkan dengan model STAD.

Selain itu dengan diterapkan model Cooperative Script dalam menyelesaikan soal telah membuat siswa belajar lebih nyaman karena siswa belajar dengan teman-temannya sendiri yang menyebabkan proses pembelajaran cenderung menyenangkan sehingga siswa lebih termotivasi untuk melakukan proses belajar. Menurut A'la (2011:98) bahwa kelebihan model cooperative script diantaranya adalah 1) melatih pendengaran, ketelitian/kecermatan, 2) setiap siswa mendapatkan peran; dan 3) melatih mengungkapkan kesalahan orang lain dengan lisan. Kelebihan dari model tersebut memberikan dampak kepada aktivitas yang positif bagi siswa, siswa dituntut untuk saling menghargai antar kelompok dalam memecahkan masalah, sehingga siswa mampu mengembangkan ide yang di milikinya untuk di sampaikan kepada teman dalam satu kelompok dari script atau bacaan yang diberikan. Kelebihan pembelajaran tersebut yang memberikan dampak kepada motivasi belajar siswa yang berimbas kepada hasil yang lebih optimal.

Hal tersebut sependapat dengan penelitian Susanti (2013) dengan judul peningkatan motivasi belajar siswa kompetensi memberikan layanan secara prima kepada pelanggan dengan metode pembelajaran cooperative script di SMK Karya Rini Yogyakarta, hasil penelitian tindakan kelas berdasarkan pengamatan proses pembelajaran menunjukkan bahwa siswa turut serta dalam kegiatan belajar, lebih aktif, hasil pengamatan terhadap motivasi belajar siswa dalam pembelajaran memberikan 
layanan secara prima kepada pelanggan melalui metode pembelajaran $\mathrm{Co}$ operative Script pada siklus I mengalami peningkatan $11,33 \%$ terbukti dengan nilai rata-rata yang dicapai pra siklus 67,86 dan nilai rata-rata yang dicapai pada siklus I meningkat menjadi 75,00. Motivasi belajar siswa pada siklus II meningkat $20,51 \%$, nilai rata- rata yang dicapai pada siklus II menjadi 81,59. Pembelajaran memberikan layanan secara prima kepada pelanggan melalui metode pembelajaran dapat meningkatkan pencapaian hasil belajar siswa yang dibuktikan dengan $90,1 \%$ pencapaian hasil belajar siswa tuntas.

Uraian di atas menunjukkan bahwa penerapan model Cooperative Script dapat meningkatkan motivasi belajar dan pencapaian ketuntasan belajar siswa pada kompetensi memberikan layanan secara prima kepada pelanggan.

Hasil tersebut memberikan gambaran kepada peneliti untuk menerapkan model pembelajaran Cooperative Script, dimana penelitian tersebut memberikan kesimpulan bahwa model pembelajaran Cooperative Script dapat meningkatan motivasi belajar siswa dan mampu berinteraksi secara kelompok untuk memberikan dorongan maupun bantuan dalam memecahkan masalah. Perbedaan hasil belajar yang diterapkan model Cooperative Script dengan model
Cooperative STAD ditunjukkan dengan hasil analisis data dengan uji t dua pihak yaitu $t_{\text {hitung }}=2,602$ dan diperoleh $\mathrm{t}_{\text {tabel }}=1,670, \quad$ karena diperoleh $t_{\text {hitung }}=2,602$ lebih dari $t_{\text {tabel }}=$ 1,670 maka tolak $H_{0}$. Hal ini menunjukkan bahwa rata-rata hasil belajar matematika siswa yang diperoleh melalui penerapan model pembelajaran Cooperative Script lebih baik dari pada rata-rata hasil belajar matematika siswa yang diperoleh melalui penerapan model pembelajaran Cooperative STAD. Berdasarkan hasil penelitian yang ditunjukkan sangat membantu peneliti untuk dapat mengatasi masalah yang terjadi di SMP Negeri 1 Banyumas tempat penelitian sehingga memberikan semangat baru dalam belajar dan berimbas kepada hasil belajar yang lebih baik. Hal tersebut ditunjukkan dengan hasil peneliti bahwa rata-rata hasil belajar matematika siswa yang diterapkan dengan model Cooperative Script sebesar 71,88 dan rata-rata hasil belajar matematika siswa yang diperoleh melalui penerapan model pembelajaran kooperatif tipe STAD sebesar 62,33.

\section{SIMPULAN}

1) ada perbedaan rata-rata hasil belajar matematika siswa yang diperoleh melalui penerapan model pembelajaran 
Cooperative Script dengan rata-rata hasil belajar matematika siswa yang diperoleh melalui penerapan model pembelajaran Cooperative STAD.

2) rata-rata hasil belajar matematika siswa yang diperoleh melalui penerapan pembelajaran Cooperative Script lebih tinggi dari pada rata-rata hasil belajar matematika siswa yang diperoleh melalui penerapan model pembelajaran Cooperative STAD. Hal ini ditunjukkan dengan rata-rata hasil belajar matematika siswa yang diterapkan dengan model pembelajaran Cooperative Script sebesar 71,88 dan rata-rata hasil belajar matematika siswa yang diperoleh melalui penerapan model pembelajaran Cooperative STAD sebesar 62,33.

\section{DAFTAR PUSTAKA}

A'la, Miftahul. 2011. Quantum Teaching. Yogyakarta: Diva press.

Huda, Miftahul. 2013. Model-model Pengajaran dan Pembelajaran. Yogyakarta: Pustaka Pelajar Offset.

Nur'aini, Dwi dan Subanji. (2010). "Proses Interaksi Berpikir Siswa Pada Pembelajaran Cooperative Script siswa Kelas XI MAN Malang II Batu Pokok Bahasan Komposisi Fungsi". Jurnal Penelitian Dosen dan Mahasiswa Fakultas Matematika dan Ilmu Pendidikan Alam Juruan Matematika Universitas Negeri Malang. 2 (1). 1-10.

Riduwan. 2010. Belajar Mudah Penelitian Untuk Guru-Karyawan dan Peneliti Pemula. Bandung: Alfabeta.

Siregar, Syofian. 2014. Statistik Parametrik Untuk Penelitian Kuantitatif Dilengkapi dengan Perhitungan Manual dan Aplikasi SPSS Versi 17. Jakarta: PT Bumi Aksara.

Sugiyono. 2010. Statistik Untuk Penelitian. Bandung: CV Alfabeta.

Suprijono, Agus. 2009. Cooperatif Learning Teori dan Aplikasi PAIKEM. Yogyakarta: Pustaka Pelajar.

Surapranata, Sumarna. 2009. Analisis, Validitas, Reliabilitas dan Interprestasi Hasil Tes Implementasi Kurikulum 2004. Bandung: PT Remaja Rosdakarya.

Susanti, Yuni. (2013). "Peningkatan Motivasi Belajar Siswa Kompetensi Memberikan Layanan Secara Prima kepada Pelanggan dengan Metode Pembelajaran Cooperative Script di SMK Karya Rini Yogyakarta". UNY. [online] 1 - 10. http://www.uny.ac.id. (20 Mei 2017).

Trianto. 2010. Mendesain Model Pembelajaran Inovatif Progresif. Jakarta: Kencana. 